\title{
Flavobacterium algicola sp. nov., isolated from marine algae
}

\author{
Mika Miyashita, ${ }^{1}$ Shuki Fujimura, ${ }^{2}$ Yasuyoshi Nakagawa, ${ }^{1}$ \\ Makoto Nishizawa, ${ }^{2}$ Noboru Tomizuka, ${ }^{2}$ Tomoyuki Nakagawa ${ }^{3}$ \\ and Junichi Nakagawa ${ }^{2}$ \\ ${ }^{1}$ Biological Resource Center (NBRC), Department of Biotechnology, National Institute of \\ Technology and Evaluation, 2-5-8 Kazusakamatari, Kisarazu, Chiba 292-0818, Japan \\ ${ }^{2}$ Department of Food Science and Technology, Faculty of Bioindustry, Tokyo University of \\ Agriculture, 196 Yasaka, Abashiri, Hokkaido 099-2493, Japan \\ ${ }^{3}$ Faculty of Applied Biological Sciences, Gifu University, 1-1 Yanagido, Gifu 501-1193, Japan
}

Correspondence

Tomoyuki Nakagawa

t_nakaga@gifu-u.ac.jp
The genus Flavobacterium belongs to the family Flavobacteriaceae, phylum Bacteroidetes, and comprises more than 50 species that have been found in various habitats, such as soil, sediment, microbial mats, fresh- and salt-water, sea ice and diseased fish. Members of the genus are also abundant in cold freshwater and marine ecosystems where they play a role in the uptake and degradation of organic materials (Bernardet \& Bowman, 2006). The genus Flavobacterium comprises many psychrophilic and psychrotolerant species isolated from Antarctica, such as Flavobacterium hibernum (McCammon et al., 1998); F. gillisiae, F. tegetincola and F. xanthum (McCammon \& Bowman, 2000); F. frigidarium (Humphry et al., 2001); F. gelidilacus, $F$. degerlachei, $F$. frigoris, F. micromati, $F$. fryxellicola and F. psychrolimnae (Van Trappen et al.,

The GenBank/EMBL/DDBJ accession numbers for the $16 \mathrm{~S}$ rRNA gene sequences of strains TC2 ${ }^{\top}$, NBRC $102676^{\top}$, NBRC $102678^{\top}$, NBRC $102679^{\top}$ and NBRC $103156^{\top}$ are AB455265, AB455257, AB455259, $A B 455260$ and $A B 455261$, respectively.

DNA-DNA hybridization values between strain $\mathrm{TC}^{\top}$ and its closest phylogenetic neighbours are available as supplementary material with the online version of this paper.
2003, 2004, 2005); F. antarcticum (Yi et al., 2005); F. segetis and F. weaverense (Yi \& Chun, 2006); and F. frigidimaris (Nogi et al., 2005). In addition, several cold-adapted species of the genus Flavobacterium have been described from regions other than Antarctica, e.g. Flavobacterium limicola from freshwater sediments (Tamaki et al., 2003), and Flavobacterium xinjiangense and Flavobacterium omnivorum from the China No. 1 glacier (Zhu et al., 2003).

This study deals with the taxonomic characterization of a fucoidan-digesting micro-organism that represents a novel species of the genus Flavobacterium. Fucoidan is a polysaccharide mainly composed of sulfated fucose that originates from brown macroalgae. It has been reported to exert several kinds of biological activities, including antithrombotic activity (Boisson-Vidal et al., 2000), antitumor activity (Maruyama et al., 2003) and inhibitory activity on viral and bacterial infections (Hoshino et al., 1998; Shibata et al., 2003). However, the potential benefits of fucoidan to the food industry have been hampered by its high molecular mass. Therefore, fucoidan-digesting microorganisms and their enzymes, which digest fucoidan into low molecular mass compounds, are currently needed by 
the food industry. Hence, fucoidan-digesting microorganisms were screened from the surface mucus of marine algae collected from the coast of the Sea of Okhotsk at Abashiri, Hokkaido, Japan.

For screening of fucoidan-degrading micro-organisms, a mineral synthetic liquid medium (MI-F) containing $0.5 \%$ (w/v) GA-fucoidan as the sole carbon source was used (Sakai et al., 1998; Nakagawa et al., 2002a). The initial pH of the medium was adjusted to 7.0. GA-fucoidan was prepared from the holdfast of cultivated Laminaria japonica by a previously reported method (Ozawa et al., 2006). Cultivation was performed aerobically with rotary shaking at $4{ }^{\circ} \mathrm{C}$ for 5 days. The liquid culture was subsequently inoculated on a MI-F plate for single colony isolation, and yellowish colonies of strain $\mathrm{TC}^{\mathrm{T}}$ were isolated. Strain $\mathrm{TC}^{\mathrm{T}}$ was subjected to a polyphasic taxonomy study after its ability to grow on GA-fucoidan as the sole carbon source had been confirmed using the MI-F liquid medium.

The almost complete 16S rRNA gene sequence, ranging from positions 28 to 1494 on the Escherichia coli numbering system (Brosius et al., 1978), was determined according to previously published procedures (Nakagawa et al., 2002b). The sequence obtained was aligned with those of representative members of the genus Flavobacterium using CLUSTAL_X (Thompson et al., 1997) and then modified manually by referring to the $16 \mathrm{~S}$ rRNA secondary structure of E. coli (Gutell et al., 1994) and using the Se-Al v2.0 alignment editor (A. Rambaut; available at http://tree.bio.ed.ac.uk/). A phylogenetic tree was reconstructed using the neighbour-joining method (Saitou \& Nei, 1987) and $K_{\text {nuc }}$ values (Kimura, 1980). Alignment gaps and unidentified base positions were not taken into consideration in the calculations. The topology of the tree was evaluated by using the bootstrap resampling method of Felsenstein (1985) with 1000 replicates. Analysis of the 16S rRNA gene sequences showed that strain $\mathrm{TC}^{\mathrm{T}}$ belonged to the genus Flavobacterium with the highest sequence similarities of $97.3,97.1,97.2$ and $97.2 \%$ to $F$. frigidarium NBRC $102676^{\mathrm{T}}, F$. frigoris NBRC $102678^{\mathrm{T}}, F$. limicola NBRC $103156^{\mathrm{T}}$ and F. psychrolimnae NBRC $102679^{\mathrm{T}}$, respectively (Fig. 1). Trees obtained by the maximumparsimony (Fitch, 1971, 1977) and maximum-likelihood (Felsenstein, 1981) methods showed almost the same topology. The $16 \mathrm{~S}$ rRNA gene sequences of strains $F$. frigidarium NBRC $102676^{\mathrm{T}}, F$. frigoris NBRC $102678^{\mathrm{T}}, F$. limicola NBRC $103156^{\mathrm{T}}$ and F. psychrolimnae NBRC $102679^{\mathrm{T}}$ were determined again in this study in order to confirm published sequences and to ascertain the authenticity of the strains. Since only these four strains showed more than $97 \% 16 \mathrm{~S}$ rRNA gene sequence similarities with strain $\mathrm{TC}_{2}^{\mathrm{T}}$, they were used as references for further taxonomic studies including phenotypic tests.

DNA-DNA hybridization between strain $\mathrm{TC}^{\mathrm{T}}$ and its four closest phylogenetic neighbours was performed using photobiotin-labelled probes in microplate wells as described by Ezaki et al. (1989). The hybridization temperature was $48.2{ }^{\circ} \mathrm{C}$ in $2 \times$ SSC buffer containing $25 \%$ formamide. Approximately $70 \%$ or greater DNADNA relatedness is considered evidence that two strains belong to the same species (Wayne et al., 1987). The results indicated that strain $\mathrm{TC}^{\mathrm{T}}$ represented a distinct species as all values of DNA-DNA relatedness were below $28 \%$ (see Supplementary Table S1 available in IJSEM Online).

The DNA G $+\mathrm{C}$ contents of strains $\mathrm{TC}^{\mathrm{T}}, F$. frigidarium NBRC $102676^{\mathrm{T}}, F$. frigoris NBRC $102678^{\mathrm{T}}, F$. limicola NBRC $103156^{\mathrm{T}}$ and F. psychrolimnae NBRC $102679^{\mathrm{T}}$ were determined according to Mesbah et al. (1989). The values

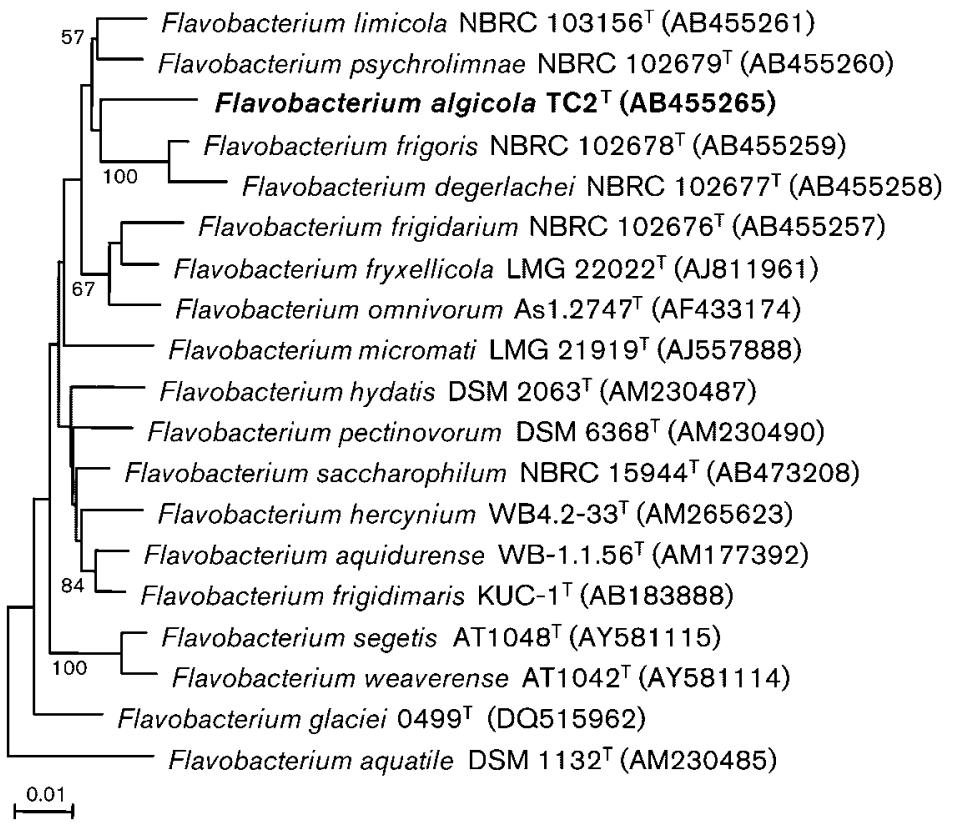

Fig. 1. Neighbour-joining tree based on $16 \mathrm{~S}$ rRNA gene sequences showing the phylogenetic position of strain $\mathrm{TC}^{\top}{ }^{\top}$. Flavobacterium aquatile DSM $1132^{\top}$ (AM230485) was used as the outgroup. Numbers at branches indicate confidence limits $>50 \%$ estimated by bootstrap analysis with 1000 resampling trials. Bar, 0.01 substitutions per nucleotide position. 
obtained were 33.9, 33.9, 34.1, 33.9 and $34.0 \mathrm{~mol} \%$, respectively. The DNA G $+\mathrm{C}$ contents of the four reference type strains were determined again in this study using the same technique in order to compare the values to those previously obtained using different techniques (Humphry et al., 2001; Tamaki et al., 2003; Van Trappen et al., 2004, 2005). The DNA G $+C$ contents obtained in this study were almost identical to the published data.

To determine whole-cell fatty acid composition, strain $\mathrm{TC}^{\mathrm{T}}$ and the four reference strains were grown in tryptic soy broth (TSB; Difco) at $15{ }^{\circ} \mathrm{C}$ for $48 \mathrm{~h}$. Fatty acid methyl esters were prepared and analysed according to the standard protocol of the Microbial Identification System (Microbial ID). The fatty acid compositions of strain $\mathrm{TC} 2^{\mathrm{T}}$ and its phylogenetic relatives are shown in Table 1 . The major fatty acids of strain $\mathrm{TC}^{\mathrm{T}}$ were iso- $\mathrm{C}_{15: 1} \mathrm{G}(10.2 \%)$, iso- $\mathrm{C}_{15: 0}(18.5 \%)$ and summed feature 3 (comprising iso$\mathrm{C}_{15: 0} 2-\mathrm{OH}$ and/or $\left.\mathrm{C}_{16: 1} \omega 7 c, 24.1 \%\right)$. These fatty acids occur in most members of the family Flavobacteriaceae (Bernardet et al., 1996, 2002). The respective proportions of several fatty acids distinguished strain $\mathrm{TC}^{\mathrm{T}}$ from its closest relatives (Table 1).

Following extraction according to Nakagawa \& Yamasato (1993) and determination using LC-MS analysis $(8000 \alpha$; Shimadzu), menaquinone- 6 was found to be the major respiratory quinone in strain $\mathrm{TC}^{\mathrm{T}}$, in line with all members of the family Flavobacteriaceae.

Morphological features of cells cultivated on tryptic soy agar (TSA; Difco) at $20{ }^{\circ} \mathrm{C}$ after $24 \mathrm{~h}$ were observed by using light microscopy. Colony morphology on TSA at $20{ }^{\circ} \mathrm{C}$ after $24 \mathrm{~h}$ was determined. Gliding motility was investigated by using phase-contrast microscopy of a hanging-drop preparation from a TSB culture (Bernardet et al., 2002). Anaerobic growth was examined by using the Anaeropack (Mitsubishi Gas Chemical). Ability to grow on marine 2216 (Difco), nutrient (Oxoid) and TS agars was examined at $15{ }^{\circ} \mathrm{C}$ after 6 days. Growth at $5-40{ }^{\circ} \mathrm{C}$ (in increments of $5{ }^{\circ} \mathrm{C}$ ) and at $\mathrm{pH} 3-11$ (in increments of 0.5 $\mathrm{pH}$ unit at $\mathrm{pH} 5-8$, and of $1 \mathrm{pH}$ unit outside of this range) was evaluated on TSA and in TSB, respectively. The $\mathrm{pH}$ of the medium was adjusted using $\mathrm{NaOH}$ and $\mathrm{HCl}$ solutions and the media obtained were sterilized by filtration. The $\mathrm{NaCl}$ range for growth was determined in TSB supplemented with several concentrations of $\mathrm{NaCl}$. TSB was prepared according to the composition of the Difco medium, except that $\mathrm{NaCl}$ was not added. The $\mathrm{NaCl}$-free medium was then supplemented with $0,2,2.5,3,3.5,4$ and $5 \% \mathrm{NaCl}(\mathrm{w} / \mathrm{v})$. The bathochromic shift test with $20 \%(\mathrm{w} / \mathrm{v})$ $\mathrm{KOH}$ (Fautz \& Reichenbach, 1980) was used to detect flexirubin-type pigments. Congo red adsorption was tested by using the methods of Bernardet et al. (2002) and Surgalla \& Beesley (1969). Only F. frigidarium NBRC $102676^{\mathrm{T}}$ absorbed the dye when the method of Bernardet $e t$ al. (2002) was used, whereas Congo red absorption was observed after 14 days at $15{ }^{\circ} \mathrm{C}$ in strain $\mathrm{TC}^{\mathrm{T}}$ and all four reference strains when the method of Surgalla \& Beesley
Table 1. Fatty acid composition (\%) of strain $\mathrm{TC}^{\top}{ }^{\top}$ and related species of the genus Flavobacterium

Strains: 1, F. algicola sp. nov. TC2 ${ }^{\mathrm{T}}$; 2, F. frigidarium NBRC $102676^{\mathrm{T}}$; 3, F. frigoris NBRC $102678^{\mathrm{T}} ;$ 4, F. psychrolimnae NBRC $102679^{\mathrm{T}} ; 5$, F. limicola NBRC $103156^{\mathrm{T}}$. tr, Trace (less than $1 \%$ of total); - , not detected. All data from this study. Fatty acids amounting to less than $1 \%$ in all strains listed are not shown.

\begin{tabular}{|c|c|c|c|c|c|}
\hline Fatty acid & 1 & 2 & 3 & 4 & 5 \\
\hline $\mathrm{C}_{14: 0}$ & 1.1 & $\operatorname{tr}$ & $\operatorname{tr}$ & $\operatorname{tr}$ & $\operatorname{tr}$ \\
\hline iso- $\mathrm{C}_{15: 1} \mathrm{G}$ & 10.2 & 5.4 & 5.5 & 2.5 & 3.1 \\
\hline anteiso- $\mathrm{C}_{15: 0} \mathrm{~A}$ & $\operatorname{tr}$ & $\operatorname{tr}$ & 1.2 & $\operatorname{tr}$ & $\operatorname{tr}$ \\
\hline iso- $\mathrm{C}_{15: 0}$ & 18.5 & 29.3 & 9.7 & 13.1 & 10.4 \\
\hline anteiso- $\mathrm{C}_{15: 0}$ & 6.7 & 3.4 & 18.9 & 8.2 & 12.5 \\
\hline $\mathrm{C}_{15: 1} \omega 6 c$ & 1.1 & 1.5 & 3.8 & 3.4 & 3.4 \\
\hline $\mathrm{C}_{15: 0}$ & 1.0 & 3.0 & 2.5 & 4.3 & 8.7 \\
\hline iso- $\mathrm{C}_{16: 1} \mathrm{H}$ & - & 1.1 & 1.3 & 2.8 & 3.6 \\
\hline iso- $\mathrm{C}_{16: 0}$ & $\operatorname{tr}$ & 1.0 & 1.8 & 1.6 & 2.1 \\
\hline $\mathrm{C}_{16: 1} \omega 5 c$ & 1.1 & $\operatorname{tr}$ & $\operatorname{tr}$ & $\operatorname{tr}$ & $\operatorname{tr}$ \\
\hline $\mathrm{C}_{16: 0}$ & 7.3 & 2.0 & 1.7 & 1.5 & 2.2 \\
\hline iso- $\mathrm{C}_{15: 0} 3-\mathrm{OH}$ & 9.9 & 11.1 & 5.9 & 5.4 & 5.7 \\
\hline iso- $\mathrm{C}_{17: 1} \omega 9 c$ & 2.3 & 8.7 & 8.8 & 12.1 & 7.0 \\
\hline anteiso- $\mathrm{C}_{17: 1} \omega 9 c$ & $\operatorname{tr}$ & $\operatorname{tr}$ & $\operatorname{tr}$ & 3.4 & 3.2 \\
\hline iso- $\mathrm{C}_{17: 0}$ & $\operatorname{tr}$ & $\operatorname{tr}$ & $\operatorname{tr}$ & 1.2 & $\operatorname{tr}$ \\
\hline $\mathrm{C}_{17: 1} \omega 8 c$ & $\operatorname{tr}$ & $\operatorname{tr}$ & $\operatorname{tr}$ & 2.3 & 2.5 \\
\hline $\mathrm{C}_{17: 1} \omega 6 c$ & $\operatorname{tr}$ & 2.0 & 3.0 & 5.1 & 4.8 \\
\hline iso- $\mathrm{C}_{16: 0} 3-\mathrm{OH}$ & - & 1.0 & 3.6 & 2.4 & 3.7 \\
\hline $\mathrm{C}_{16: 0} 3-\mathrm{OH}$ & 5.4 & $\operatorname{tr}$ & 1.2 & $\operatorname{tr}$ & 1.1 \\
\hline $\mathrm{C}_{18: 1} \omega 5 c$ & $\operatorname{tr}$ & $\operatorname{tr}$ & $\operatorname{tr}$ & 1.0 & $\operatorname{tr}$ \\
\hline iso- $\mathrm{C}_{17: 0} 3-\mathrm{OH}$ & 5.2 & 11.3 & 8.1 & 8.4 & 8.1 \\
\hline $\mathrm{C}_{17: 0} 2-\mathrm{OH}$ & $\operatorname{tr}$ & $\operatorname{tr}$ & 1.7 & 1.1 & 1.9 \\
\hline $\mathrm{C}_{17: 0} 3-\mathrm{OH}$ & - & $\operatorname{tr}$ & $\operatorname{tr}$ & $\operatorname{tr}$ & 1.0 \\
\hline Unknown* & 1.0 & 2.1 & 1.2 & 1.9 & 1.2 \\
\hline Summed feature $\dagger 3$ & 24.1 & 8.5 & 12.7 & 6.6 & 5.4 \\
\hline Summed feature 4 & $\operatorname{tr}$ & 1.9 & 1.0 & 6.6 & 1.7 \\
\hline
\end{tabular}

*The equivalent chain-length (ECL) of the unknown fatty acid was 16.582 .

$\dagger$ Summed features represent groups of two or three fatty acids that could not be separated by GLC with the MIDI system. Summed feature 3, iso- $\mathrm{C}_{15: 0} 2-\mathrm{OH}$ and/or $\mathrm{C}_{16: 1} \omega 7 c$; summed feature 4 , anteiso- $\mathrm{C}_{17: 1} \mathrm{~B}$ and/or iso- $\mathrm{C}_{17: 1} \mathrm{I}$.

(1969) was used. Production of catalase, oxidase and $\mathrm{H}_{2} \mathrm{~S}$, reduction of nitrate, degradation of aesculin, agar, alginate, casein, CM-cellulose, chitin, DNA, gelatin, pectin, starch and L-tyrosine, and production of brown diffusible pigment on L-tyrosine agar were examined according to the methods of Lewin \& Lounsbery (1969), Smibert \& Krieg (1981) and Barrow \& Feltham (1993) by using one-fifth strength TSB as the basal medium. Tests in the commercial API ZYM, API 20NE and API 20E systems (bioMérieux) were performed by TechnoSuruga Laboratory (Shizuoka, Japan) according to the instructions of the manufacturer. The phenotypic characteristics of strain $\mathrm{TC}^{\mathrm{T}}$ are given in the species description and in Table 2. 
Table 2. Phenotypic characteristics that differentiate strain $\mathrm{TC}^{\top}$ from related species of the genus Flavobacterium

Species: 1, F. algicola sp. nov. TC2 ${ }^{\mathrm{T}} ; 2$, F. frigidarium NBRC $102676^{\mathrm{T}}$; 3, F. frigoris NBRC $102678^{\mathrm{T}} ;$ 4, F. psychrolimnae NBRC $102679^{\mathrm{T}} ; 5$, F. limicola NBRC $103156^{\mathrm{T}}$. All data from this study. +, Positive; -, negative; $\mathrm{v}$, variable. All strains are positive for growth on TSA and for degradation of aesculin and are negative for gliding motility, production of $\mathrm{H}_{2} \mathrm{~S}$ and flexirubin pigments, degradation of CMcellulose, pectin, chitin and DNA, and nitrate reduction. Data from the original descriptions (Humphry et al., 2001; Tamaki et al., 2003; Van Trappen et al., 2004, 2005) are shown in parentheses.

\begin{tabular}{|lccccc|}
\hline Characteristic & $\mathbf{1}$ & $\mathbf{2}$ & $\mathbf{3}$ & $\mathbf{4}$ & $\mathbf{5}$ \\
\hline Growth on nutrient agar & + & + & $+(-)$ & + & + \\
Tolerance to $3 \% \mathrm{NaCl}$ & + & + & + & - & - \\
Growth at $25{ }^{\circ} \mathrm{C}$ & + & - & + & + & + \\
Congo red adsorption & + & + & $+(-)$ & $+(-)$ & + \\
Acid from carbohydrates & + & - & - & - & - \\
Degradation of: & & & & & \\
$\quad$ Gelatin & - & $-(+)$ & - & - & $-(+)$ \\
Casein & - & + & + & + & + \\
Starch & + & - & + & + & + \\
Agar & - & - & - & - & $-(+)$ \\
Alginate & + & $+(-)$ & - & - & - \\
Tyrosine & - & - & $-(+)$ & - & $-(+)$ \\
Brown pigment on & - & $-(+)$ & - & - & $-(+)$ \\
tyrosine agar & & & & & \\
ONPG hydrolysis & + & - & - & + & - \\
DNA G+C content & 3.9 & 33.9 & 34.1 & 34 & 33.9 \\
(mol\%) & & & & & \\
\hline
\end{tabular}

The phylogenetic analysis and DNA-DNA hybridization clearly demonstrated that strain $\mathrm{TC}^{\mathrm{T}}$ represents a new species of the genus Flavobacterium that can be differentiated from closely related species by the phenotypic characteristics listed in Table 2. The name Flavobacterium algicola sp. nov. is proposed for this species.

\section{Description of Flavobacterium algicola sp. nov.}

Flavobacterium algicola (al.gi' co.la. L. fem. n. alga seaweed, alga; L. suff. -cola inhabitant, dweller; N.L. masc. n. algicola alga-dweller)

Cells are Gram-staining-negative, non-spore-forming, aerobic rods, $0.7-0.8 \mu \mathrm{m}$ in diameter and $1.5-2.0 \mu \mathrm{m}$ in length. Gliding motility is not observed. Colonies on TSA are yellow, translucent, circular and convex with entire margins. Growth occurs on marine 2216, nutrient and trypticase soy agars. The temperature range for growth is 5-25 ${ }^{\circ} \mathrm{C}$ (optimum, $20{ }^{\circ} \mathrm{C}$ ). The $\mathrm{pH}$ range for growth is 5.5-8 (optimum, $\mathrm{pH}$ 7). The salinity range for growth is 0 $3 \% \mathrm{NaCl}$ (optimum, $0 \%$ ). Flexirubin-type pigments are not produced. Congo red is absorbed. Brown diffusible pigment is not produced on L-tyrosine agar. Catalase and oxidase activities are present. Nitrate is not reduced. Hydrogen sulfide is not produced. Aesculin, alginate and starch are degraded, but agar, casein, CM-cellulose, chitin, DNA, gelatin, pectin and tyrosine are not. $N$-acetyl-Dglucosamine, glucose, maltose, D-mannitol and D-mannose are utilized, but adipate, L-arabinose, caprate, citrate, gluconate, malate and phenylacetate are not utilized (API 20NE). Acids are produced from D-mannitol and sucrose, but not from L-arabinose, D-amygdalin, glucose, inositol, melibiose, L-rhamnose or D-sorbitol (API 20E). $\mathrm{N}$-acetylD-glucosaminidase, acid phosphatase, alkaline phosphatase, leucine arylamidase and naphthol-AS-BI-phosphohydrolase activities are present, but $\alpha$-chymotrypsin, esterase (C4), esterase-lipase (C8), $\alpha$-fucosidase, $\alpha$-galactosidase, $\beta$ galactosidase, $\beta$-glucuronidase, $\alpha$-glucosidase, $\beta$-glucosidase, lipase (C14), $\alpha$-mannosidase, trypsin, cystine arylamidase and valine arylamidase activities are absent (API ZYM). The major respiratory quinone is menaquinone- 6 . The major fatty acids (more than $5 \%$ of total) are iso- $\mathrm{C}_{15: 1}$ $\mathrm{G}$, iso- $\mathrm{C}_{15: 0}$, anteiso- $\mathrm{C}_{15: 0}, \mathrm{C}_{16: 0}$, iso- $\mathrm{C}_{15: 0} 3-\mathrm{OH}, \mathrm{C}_{16: 0}$ 3- $\mathrm{OH}$, iso- $\mathrm{C}_{17: 0} 3-\mathrm{OH}$ and summed feature 3 (comprising iso- $\mathrm{C}_{15: 0} 2-\mathrm{OH}$ and/or $\left.\mathrm{C}_{16: 1} \omega 7 c\right)$. The DNA G $+\mathrm{C}$ content of the type strain is $33.9 \mathrm{~mol} \%$.

The type strain is $\mathrm{TC}^{\mathrm{T}}\left(=\mathrm{NBRC} 102673^{\mathrm{T}}=\mathrm{CIP} 109574^{\mathrm{T}}\right)$ isolated from marine algae from the coast of the Sea of Okhotsk at Abashiri, Hokkaido, Japan.

\section{Acknowledgements}

We are grateful to Dr Takashi Ito, Ms Megumi Ando and Ms Tomomi Chida, Department of Food Science and Technology, Tokyo University of Agriculture, for their skilful assistance. This work was supported in part by the Research for Promoting Technological Seed from the Japan Science and Technology Agency (JST).

\section{References}

Barrow, G. I. \& Feltham, R. K. A. (1993). Cowan and Steel's Manual for the Identification of Medical Bacteria, 3rd edn. Cambridge: Cambridge University Press.

Bernardet, J.-F. \& Bowman, J. P. (2006). The Genus Flavobacterium. In The Prokaryotes: a Handbook on the Biology of Bacteria, 3rd edn, vol. 7, pp. 481-531. Edited by M. Dworkin, S. Falkow, E. Rosenberg, K.-H. Schleifer \& E. Stackebrandt. New York: Springer.

Bernardet, J.-F., Segers, P., Vancanneyt, M., Berthe, F., Kersters, K. \& Vandamme, P. (1996). Cutting a Gordian knot: emended classification and description of the genus Flavobacterium, emended description of the family Flavobacteriaceae, and proposal of Flavobacterium hydatis nom. nov. (basonym, Cytophaga aquatilis Strohl and Tait 1978). Int J Syst Bacteriol 46, 128-148.

Bernardet, J.-F., Nakagawa, Y. \& Holmes, B. (2002). Proposed minimal standards for describing new taxa of the family Flavobacteriaceae and emended description of the family. Int J Syst Evol Microbiol 52, 1049-1070.

Boisson-Vidal, C., Chaubet, F., Chevolot, L., Sinquin, C., Theveniaux, J., Millet, J., Sternberg, C., Mulloy, B. \& Fisher, A. M. (2000). Relationship between antithrombotic activities of fucans and their structure. Drug Dev Res 51, 216-224.

Brosius, J., Palmer, M. L., Kennedy, P. J. \& Noller, H. F. (1978). Complete nucleotide sequence of a $16 \mathrm{~S}$ ribosomal RNA gene from Escherichia coli. Proc Natl Acad Sci U S A 75, 4801-4805. 
Ezaki, T., Hashimoto, Y. \& Yabuuchi, E. (1989). Fluorometric deoxyribonucleic acid-deoxyribonucleic acid hybridization in microdilution wells as an alternative to membrane filter hybridization in which radioisotopes are used to determine genetic relatedness among bacterial strains. Int J Syst Bacteriol 39, 224-229.

Fautz, E. \& Reichenbach, H. (1980). A simple test for flexirubin-type pigments. FEMS Microbiol Lett 8, 87-91.

Felsenstein, J. (1981). Evolutionary trees from DNA sequences: a maximum likelihood approach. J Mol Evol 17, 368-376.

Felsenstein, J. (1985). Confidence limits on phylogenies: an approach using the bootstrap. Evolution 39, 783-791.

Fitch, W. M. (1971). Toward defining the course of evolution: minimum change for a specific tree topology. Syst Zool 20, 406-416.

Fitch, W. M. (1977). On the problem of discovering the most parsimonious tree. Am Nat 111, 223-257.

Gutell, R. R., Larsen, N. \& Woese, C. R. (1994). Lessons from an evolving rRNA: $16 \mathrm{~S}$ and $23 \mathrm{~S}$ rRNA structures from a comparative perspective. Microbiol Rev 58, 10-26.

Hoshino, T., Hayashi, T., Hayashi, K., Hamada, J., Lee, J. B. \& Sankawa, U. (1998). An antivirally active sulfated polysaccharide from Sargassum horneri (TURNER) C. AGARDH. Biol Pharm Bull 21, 730-734.

Humphry, D. R., George, A., Black, G. W. \& Cummings, S. P. (2001) Flavobacterium frigidarium sp. nov., an aerobic, psychrophilic, xylanolytic and laminarinolytic bacterium from Antarctica. Int $J$ Syst Evol Microbiol 51, 1235-1243.

Kimura, M. (1980). A simple method for estimating evolutionary rates of base substitutions through comparative studies of nucleotide sequences. J Mol Evol 16, 111-120.

Lewin, R. A. \& Lounsbery, D. M. (1969). Isolation, cultivation and characterization of flexibacteria. J Gen Microbiol 58, 145-170.

Maruyama, H., Tamauchi, H., Hashimoto, M. \& Nakano, T. (2003). Antitumor activity and immune response of Mekabu fucoidan extracted from Sporophyll of Undaria pinnatifida. In Vivo 17, 245249.

McCammon, S. A. \& Bowman, J. P. (2000). Taxonomy of Antarctic Flavobacterium species: description of Flavobacterium gillisiae sp. nov., Flavobacterium tegetincola sp. nov. and Flavobacterium xanthum sp. nov., nom. rev., and reclassification of [Flavobacterium] salegens as Salegentibacter salegens gen. nov., comb. nov. Int J Syst Evol Microbiol 50, 1055-1063.

McCammon, S. A., Innes, B. H., Bowman, J. P., Franzmann, P. D. Dobson, S. J., Holloway, P. E., Skerratt, J. H., Nichols, P. D. \& Rankin, L. M. (1998). Flavobacterium hibernum sp. nov., a lactose-utilizing bacterium from a freshwater Antarctic lake. Int J Syst Bacteriol 48, 1405-1412.

Mesbah, M., Premachandran, U. \& Whitman, W. B. (1989). Precise measurement of the $\mathrm{G}+\mathrm{C}$ content of deoxyribonucleic acid by highperformance liquid chromatography. Int J Syst Bacteriol 39, 159-167.

Nakagawa, Y. \& Yamasato, K. (1993). Phylogenetic diversity of the genus Cytophaga revealed by $16 \mathrm{~S}$ rRNA sequencing and menaquinone analysis. J Gen Microbiol 139, 1155-1161.

Nakagawa, T., Yamada, K., Miyaji, T. \& Tomizuka, N. (2002a). Coldactive pectinolytic activity of psychrophilic-basidiomycetous yeast Cystofilobasidium capitatum strain PPY-1. J Biosci Bioeng 94, 175-177.

Nakagawa, Y., Sakane, T., Suzuki, M. \& Hatano, K. (2002b). Phylogenetic structure of the genera Flexibacter, Flexithrix, and Microscilla deduced from $16 \mathrm{~S}$ rRNA sequence analysis. J Gen Appl Microbiol 48, 155-165.
Nogi, Y., Soda, K. \& Oikawa, T. (2005). Flavobacterium frigidimaris sp. nov., isolated from Antarctic seawater. Syst Appl Microbiol 28, 310-315.

Ozawa, T., Yamamoto, J., Yamagishi, T., Yamazaki, N. \& Nishizawa, M. (2006). Two fucoidans in the holdfast of cultivated Laminaria japonica. J Nat Med 60, 236-239.

Saitou, N. \& Nei, M. (1987). The neighbor-joining method: a new method for reconstructing phylogenetic trees. Mol Biol Evol 4, 406-425.

Sakai, Y., Nakagawa, T., Shimase, M. \& Kato, N. (1998). Regulation and physiological role of the DAS1 gene, encoding dihydroxyacetone synthase, in the methylotrophic yeast Candida boidinii. J Bacteriol 180, 5885-5890.

Shibata, H., limuro, M., Uchiya, N., Kawamori, T., Nagaoka, M., Ueyama, S., Hashimoto, S., Yokokura, T., Sugimura, T. \& Wakabayashi, K. (2003). Preventive effects of Cladosiphon fucoidan against Helicobacter pylori infection in Mongolian gerbils. Helicobacter 8, 59-65.

Smibert, R. M. \& Krieg, N. R. (1981). General characterization. In Manual of Methods for General Microbiology, pp. 409-443. Edited by P. Gerhardt, R. G. E. Murray, R. N. Costilow, E. W. Nester, W. A. Wood, N. R. Krieg \& G. B. Phillips. Washington, DC: American Society for Microbiology.

Surgalla, M. J. \& Beesley, E. D. (1969). Congo red-agar plating medium for detecting pigmentation in Pasteurella pestis. Appl Microbiol 18, 834-837.

Tamaki, H., Hanada, S., Kamagata, Y., Nakamura, K., Nomura, N., Nakano, K. \& Matsumura, M. (2003). Flavobacterium limicola sp. nov., a psychrophilic, organic-polymer-degrading bacterium isolated from freshwater sediments. Int J Syst Evol Microbiol 53, 519-526.

Thompson, J. D., Gibson, T. J., Plewniak, F., Jeanmougin, F. \& Higgins, D. G. (1997). The CLUSTAL_X windows interface: flexible strategies for multiple sequence alignment aided by quality analysis tools. Nucleic Acids Res 25, 4876-4882.

Van Trappen, S., Mergaert, J. \& Swings, J. (2003). Flavobacterium gelidilacus sp. nov., isolated from microbial mats in Antarctic lakes. Int J Syst Evol Microbiol 53, 1241-1245.

Van Trappen, S., Vandecandelaere, I., Mergaert, J. \& Swings, J. (2004). Flavobacterium degerlachei sp. nov., Flavobacterium frigoris sp. nov. and Flavobacterium micromati sp. nov., novel psychrophilic bacteria isolated from microbial mats in Antarctic lakes. Int J Syst Evol Microbiol 54, 85-92.

Van Trappen, S., Vandecandelaere, I., Mergaert, J. \& Swings, J. (2005). Flavobacterium fryxellicola sp. nov. and Flavobacterium psychrolimnae sp. nov., novel psychrophilic bacteria isolated from microbial mats in Antarctic lakes. Int J Syst Evol Microbiol 55, 769-772.

Wayne, L. G., Brenner, D. J., Colwell, R. R., Grimont, P. A. D., Kandler, O., Krichevsky, M. I., Moore, L. H., Moore, W. E. C., Murray, R. G. E. \& other authors (1987). International Committee on Systematic Bacteriology. Report of the ad hoc committee on reconciliation of approaches to bacterial systematics. Int J Syst Bacteriol 37, 463-464.

Yi, H. \& Chun, J. (2006). Flavobacterium weaverense sp. nov. and Flavobacterium segetis sp. nov., novel psychrophiles isolated from the Antarctic. Int J Syst Evol Microbiol 56, 1239-1244.

Yi, H., Oh, H. M., Lee, J. H., Kim, S. J. \& Chun, J. (2005). Flavobacterium antarcticum sp. nov., a novel psychrotolerant bacterium isolated from the Antarctic. Int J Syst Evol Microbiol 55, 637-641.

Zhu, F., Wang, S. \& Zhou, P. (2003). Flavobacterium xinjiangense sp. nov. and Flavobacterium omnivorum sp. nov., novel psychrophiles from the China No. 1 glacier. Int J Syst Evol Microbiol 53, 853-857. 